\title{
HOW DOES FIRM SIZE AND CAPITAL STRUCTURE AFFECT FIRM VALUE?
}

\author{
Radhika Putri Nursetya ${ }^{1}$, Lina Nur Hidayati ${ }^{*}$ \\ 1,2 Universitas Negeri Yogyakarta, Indonesia \\ e-mails: ${ }^{1}$ radhika.putri2016@student.uny.ac.id; ${ }^{2}$ lina_nurhidayati@uny.ac.id
}

Received November 25, 2020; accepted December 30, 2020; published January 29, 2021.

\begin{abstract}
Objective: This paper explores whether the firm size and capital structure have an impact on corporate valuation. Then it will raise profitability as an intervening variable on the effect of company size and capital structure on corporate valuation. Research Design \& Methods: Data gathering method is finalized by using the documentation method. In this study, data were obtained from published financial reports. Samples from this study were 30 manufacturing companies listed on the Indonesia Stock Exchange. Findings: The results exhibited that firm size affected profitability and firm value. In the meantime, the capital structure has a big influence on performance and does not affect the company's valuation. Profitability has a positive effect on corporate value. This study also concludes that profitability can mediate firm size to firm value. Conversely, profitability cannot mediate capital structure on corporate value. Implications \& Recommendations: This study offers empirical evidence that profitability can be an intervening variable in firm size's effect on firm value. In further research, other variables can be added, which are considered to mediate company size and capital structure on corporate value. Contribution \& Value Added: This study's results contribute to the financial literature, especially those related to public corporations' value in Indonesia. As a practical contribution, stockholders can use this study's outcomes as additional information in investment decisions.
\end{abstract}

Keywords: firm size; capital structure; profitability; firm value.

JEL codes: M4, L6, L25

Article type: research paper

\section{INTRODUCTION}

Company value can be interpreted as the prominent aspect that investors assess because of its success rate related to the stock value, as shown from the firm's value. Research on company value is considered essential and beneficial for many parties. For example, this research will provide crucial and useful information, especially for investors and potential investors. In this era of globalization, technological advances have brought more and more companies into the business world, increasing many people's desire to invest in a particular company. Thus, the results of this study will guide prospective investors to invest correctly.

In an increasingly advanced era like today, more and more companies are growing and entering the industry. These companies strive to achieve company goals and compete to be the best company. In general, companies have goals in the short-term and long-term periods. The company's short-term goal is to get the maximum profit or profit as much as possible by taking advantage of the limited resources available in the company (such as capital, human resources, and information). Meanwhile, the company's long-term goal is to prosper its shareholders. This goal is done to increase the company's value as much as possible. Later the increase in company value can be reflected in its share price.

According to Rahayu \& Sari (2018), company value is a particular condition that a company has attained and reflected in its shares' market price. Thus, it can be concluded that company value is one 
of the benchmarks used by investors to measure a company's success rate. A high share price reflects the increasing welfare of shareholders, thus attracting investors to invest in or invest in the company. Many factors can affect firm value, but in this study, only three elements are used: company size, capital structure, and profitability, which are the intervening variables.

According to Rusdaniah (2019), profitability is the most favorite for investors because of the more significant profits, the greater its return. According to Gitman \& Zutter (2015), profitability is the company's capability to create profits related to sales, capital, or total assets. Investors view higher earnings because they are considered to have good financial performance and have promising prospects. According to Pratiwi (2018), the signaling theory states that an increase in profit will positively signal investors that the company is profitable. This condition will raise the motivation of stockholders to invest in a particular corporation. In this study, profitability denoted by return on assets (ROA) will act as an intervening variable, meaning that profitability will serve as a bridge between the independent and dependent variables.

According to Mardiyati, Abrar, \& Ahmad (2015), the definition of company size is the scale of a company's size or size as measured by the company's total assets. Meanwhile, according to Hermuningsih (2012), firm size is a pointer that displays the company's economic power. Thus, it can be concluded that firm size is a measure of the firm's strength relating to its finances, which can be seen through the total assets. According to Narita (2012), company size is always associated with its amount of wealth. Therefore, a company with a large scale will be considered by investors and will fascinate investors to invest in the business. This matter will undoubtedly increase demand for shares so that the stock price will increase, which will automatically increase the company's value. Indriyani (2017) declares that firm size is considered proficient of influencing company value. The greater the firm's size will affect its ease in obtaining funding sources that can maximize its operational activities so that its goals can be achieved.

To achieve company goals and support all of its business activities, companies need funds. According to Margaretha \& Ramadhan (2010), the right funding decision can be seen from the capital structure, namely financial decisions related to the composition of debt, preferred stock, and common stock to be used by the company. The use of the wealth structure in the debt system is hazardous for the company, although at a certain level, the use of debt can be profitable for the company. The use of debt that is not burdening the company or not exceeding its ability to pay can indeed increase its value. That is because debt can reduce tax burdens and agency costs so that its net income is higher. However, excessive use of debt will result in the company experiencing financial difficulties. The greater its debt, the higher its risk of bankruptcy, which can reduce its value.

This study seeks to assess the firm size and capital structure on corporate valuation with profitability as a mediating variable based on the background. The remaining part of the paper is arranged as conform to the section as follows. Section 2 of the literature review and Section 3 define the method. Empirical results are stated in Section 4, while Section 5 suggests conclusions of the paper. This investigation proposes determining the firm size and capital structure on corporate value with profitability as a mediating variable based on the background. The remaining part of the paper is arranged as conform to the section as follows. Section 2 literature review, and section 3 defines the method. In Section 4, empirical findings are reported, while Section 5 proposes the paper's conclusions.

\section{LITERATURE REVIEW}

The influence of liquidity, capital structure, and size on firm value with profitability as a mediation variable was examined by Rusdaniah (2019). The results depicted that firm value, firm size, and profitability were not positively influenced by the capital structure. This study also states that the capital structure does not affect profitability. Conversely, firm size has a positive effect on profitability. This study also explains that profitability can mediate the effect of capital structure on firm value and firm size on firm value. 
The effect of capital structure, company size, and liquidity on firm value with profitability as a moderating variable was investigated by Ardiana \& Chabachib (2015). The findings exhibited that capital structure has a negative effect on profitability, while firm size positively affects profitability. Capital structure, firm size, and profitability have a positive effect on firm value. This study also concluded that the influence of the capital structure on company value could not be mediated by profitability. Still, it can mediate the impact of company size on company valuation.

Anisa (2019) also explored whether the firm value is affected by capital structure, firm size, and investment. The profitability variable is also introduced as a moderating variable. This study explained that the composition of capital and firm size has a positive influence on profitability. The capital structure does not affect firm value, while firm size and profitability positively affect firm value. This study also concludes that the effect of the capital structure on firm value will interfere with profitability. Besides, profitability is often shown to be an interfering variable between firm size and firm value.

While Widyantari \& Yadnya (2017) conducted an exploration of the influence of leverage, profitability, and size on firm value, the findings displayed that the capital structure had a negative effect on firm value, while profitability and size positively affected firm value.

The effect of capital structure, profitability, and business size on corporate value was explored by Astuti (2018). This study clarified that capital structure affects firm value, although profitability and firm size do not affect corporate value. Dewi \& Wirajaya (2013) proved that capital structure has a negative effect on corporate value. Profitability has a positive impact on firm value, while firm size does not affect corporate value.

The impact of leverage and scale on corporate value was also investigated by Astriana, Nurcholisah, \& Nurhayati (2019). This study indicates that firm value is influenced by leverage, but firm size does not affect firm value. Dwiastuti \& Dillak (2019) examined the effect of leverage, profitability, and company size on firm value. This study explains that company size and leverage did not affect firm value. Profitability, meanwhile, has a favorable effect on firm valuation.

The effect of market size, interest rates, and leverage on profitability was scrutinized by Hutabarat, Sedana, \& Bagus (2017). This research displays that company size has a positive effect on profitability, and capital structure has a negative effect on profitability. Sukmayanti \& Triaryati (2019) examined the influence of capital structure, liquidity, and company size on property and real estate companies' profitability. In this study, it is concluded that capital structure has no effect on profitability and firm size has a negative effect on profitability. Meithasari (2017) reviewed research on factors that affect profitability. In this analysis, capital structure has a negative impact on profitability, while profitability is not influenced by firm size. Wikardi \& Wiyani (2017) researched the influence of leverage, firm size, assets turnover, inventory turnover, and sales on profitability. This study concludes that the debt-to-equity ratio has a negative effect on profitability, and firm size positively affects profitability.

\section{METHODS}

\section{Sample}

This investigation was shepherded at corporations listed on the Indonesia Stock Exchange. The sample companies are manufacturing companies that are listed during 2016-2018. This research's data source is taken from the financial statements accessed through www.idx.co.id. The number of samples obtained were 30 manufacturing companies and had met the required sample selection criteria.

\section{Operational Definition of Variables}

Firm value is the dependent variable. The corporate value itself is one of the stockholders' benchmarks to measure a company's success rate, which can be seen from its share price. According to Brigham \& Houston (2016), company value calculation is as follows (Equation 1). 
$\mathrm{PBV}=\frac{\text { Stock market prices }}{\text { Share book value }}$

Firm size is a description of its size, as seen from its total assets (Dewi \& Sudiartha, 2017). Meithasari (2017) says that to measure the size of a company according to critical resources is as follows (Equation 2).

Firm size $=\operatorname{Ln}($ Total asset $)$ Equation 2

Capital structure compares foreign capital and its capital, where the foreign capital comes from debt (Husnan, 2000). According to Darya \& Putu (2019), the debt to equity ratio can be formulated (Equation 3).

DER $=\frac{\text { The total amount of debt }}{\text { Total equity }}$ Equation 3

The mediating variable is a variable that affects the direct relationship between the independent variable and the dependent variable, resulting in an indirect relationship Umar (2005). In this research, the mediating variable used is profitability represented by Return On Assets, which is the profitability ratio used to measure or assess its effectiveness in making profits by employing the total assets (Hasanah \& Enggariyanto, 2018). According to Brigham \& Houston (2016), the ROA calculation is as follows (Equation 4).

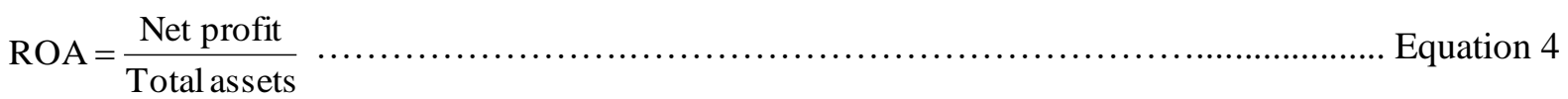

\section{Data analysis technique}

In this research, hypothesis testing used regression and path analysis. A regression test was implemented to conclude the dependent variable's relationship or impact on the dependent variable. Riduwan \& Kuncoro (2012) stated that Path analysis was carried out to investigate the relationships between variables and to know the direct and indirect effects of independent variables' on the dependent variable. Variables that affect the relationship between the dependent variable and independent variable are called intervening variables. This study observed firm size and leverage on corporate value with profitability as an intervening variable.

\section{FINDING}

The data that has been collected was then analyzed using a regression test. The following are the results of the regression test in this study.

Table 1. Regression Test Results Model 1

\begin{tabular}{lcc}
\hline \multicolumn{1}{c}{ Variable } & Regression Coefficient & Sig. \\
\hline (constant) & -0.040 & 0.385 \\
\hline SIZE & 0.004 & 0.014 \\
\hline DER & -0.015 & 0.042 \\
\hline
\end{tabular}

Source: Secondary data processed

Based on table 1, the regression equation is obtained as follows (Equation 5).

$\mathrm{ROA}=-0.040+0.004 \mathrm{SIZE}-0.015 \mathrm{DER}+\varepsilon$ Equation 5

The results depicted that SIZE had a t-value of 2.520 with a significance level smaller than the predetermined significance level, i.e., $0.014<0.05$. SIZE had a positive and significant effect on ROA. Likewise, DER had a t value of -2.063 with a significance level smaller than the predetermined significance level of $0.042<0.05$. DER had a negative and significant effect on ROA.

Based on table 2, the regression equation was obtained as follows (Equation 6).

$\mathrm{PBV}=-2.641+0.110 \mathrm{SIZE}-0.093 \mathrm{DER}+18.837 \mathrm{ROA}+\varepsilon$ Equation 6 
Table 2. Regression Test Results Model 2

\begin{tabular}{lcc}
\hline \multicolumn{1}{c}{ Variable } & Regression Coefficient & Sig. \\
\hline (constant) & -2.641 & 0.037 \\
\hline SIZE & 0.110 & 0.014 \\
\hline DER & -0.093 & 0.638 \\
\hline ROA & 18.837 & 0.000 \\
\hline
\end{tabular}

Source: Secondary data processed

The results displayed that SIZE had a t-value of 2.497, meaning less than the predetermined 0.014 $<0.05$ meaning amount. The influence of SIZE on PBV is positive and important. Meanwhile, DER had a $0.472 \mathrm{t}$ value, with a higher meaning level than the default $0.638>0.05$ level. PBV was not influenced by DER. The t-value of ROA is 6,518, and the meaning amount is smaller than $0,000<0.05$ as predestined. The result showed that ROA had a positive and important impact on PBV. Furthermore, $\mathrm{F}$ tests were performed to simultaneously determine the independent variable's influence on the dependent variable.

Table 3. F-test Results Model 1

\begin{tabular}{ccc}
\hline Model & F & Sig. \\
\hline Regression & 5.479 & 0.006 \\
\hline Source: Secondary data processed & &
\end{tabular}

Source: Secondary data processed

Table 3 of the F Model 1 test found a F value of 5.479 with a meaning level of 0.006 . The significance value was less than 0.05; it indicates that SIZE and DER as independent variables affected ROA as the dependent variable.

Table 4. F-test Results Model 2

\begin{tabular}{ccc}
\hline Model & F & Sig. \\
\hline Regression & 21.887 & 0.000 \\
\hline
\end{tabular}

Source: Secondary data processed

In Table 4, the F Model 2 test revealed that the F value calculated was 21,887, with a meaning level of 0,000 . The value was below 0.05; it showed that the PBV was affected by SIZE, DER, and ROA as independent variables.

Furthermore, the path analysis test was conducted to establish the independent variable's indirect effect on the dependent variable. Here was the calculation of the path analysis (Figure 1).

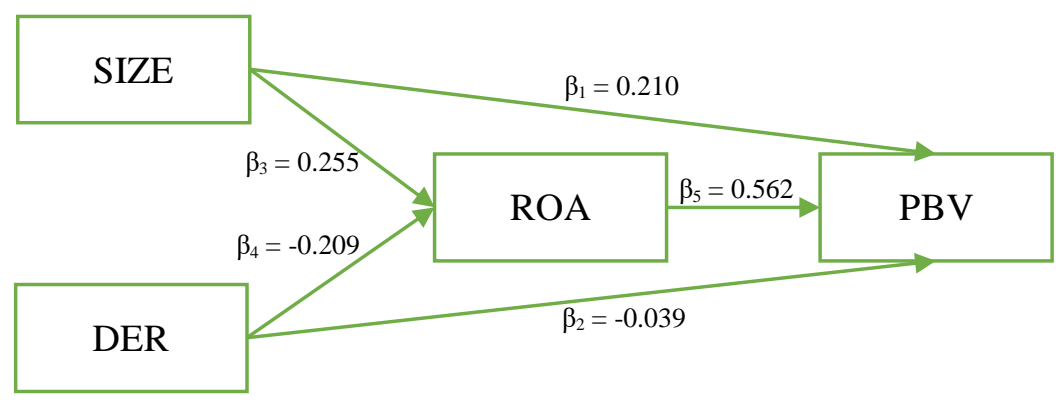

Figure 1. Path Analysis

Based on Figure 1, the calculation of the indirect effect of company size on corporate value was obtained with profitability as a mediating variable, as follows.

$$
\begin{aligned}
\text { Indirect effect }(\mathrm{SIZE}) & =\beta_{1}+\left(\beta_{3} x \beta_{5}\right) \\
= & 0.210+(0.255 \mathrm{x} 0.562) \\
= & 0.353
\end{aligned}
$$

The magnitude of the direct influence of SIZE on PBV was 0.210. Meanwhile, the magnitude of the indirect effect was 0.353. Because the value of the indirect effect was greater than the value of the direct effect or $0.353>0.210$, it was concluded that profitability could intervene in the impact of firm size on corporate value. 
Build upon Figure 1, the calculation of the indirect effect of leverage on corporate value was obtained using profitability as a mediating variable, as follows.

$$
\begin{aligned}
\text { Indirect effect }(\mathrm{DER}) & =\beta_{2}+\left(\beta_{4} x \beta_{5}\right) \\
= & -0.039+(-0.209 \times 0.562) \\
= & -0.156
\end{aligned}
$$

The gauge of the direct effect of DER on PBV is -0.039. In comparison, the magnitude of the indirect effect was -0.156 . Because the value of the indirect effect was smaller than the value of the direct effect or $-0.156<-0.039$, it was concluded that profitability was not adequate to intervene the effect of capital structure on corporate value.

\section{DISCUSSION}

\section{The Effect of Company Size on Profitability}

The size had a t-value of 2.520 with a significance of 0.014 from the regression analysis. The importance value of less than $0,05(0,014<0,05)$ showed that the size of the company has a positive impact on profitability in the manufacturing sector listed on the Indonesia Stock Exchange.

This study's results were matched with Wikardi \& Wiyani (2017) research, which states that company size positively affects profitability. This outcome can be explained from the data's value on manufacturing companies' sample in 2016-2018 in this study. For example, Surya Toto Indonesia Tbk (TOTO), in 2016, had a SIZE value of 28.58 with a ROA value of 0.06. In 2017 the company's SIZE value increased to 28.67 , followed by an increase in the ROA value to 0.09 . The same thing happened in 2018, where the SIZE increased to 28.70 and was followed by the rise in the ROA value, which was getting greater, amounting to 0.12 .

Thus, in this study, the greater the size of the company, the higher the profitability. Large companies are believed to have a more stable and more robust financial condition to be considered more capable of financing the company's operational activities. The company's operational activities that can continue well will open up opportunities for the company to get bigger profits. Thus, it can be concluded that size has a positive effect on profitability.

\section{The Effect of Capital Structure on Profitability}

Based on the regression analysis results, the capital structure variable had a t-value of -2.063 with a significance of 0.042 . The significance value of less than $0.05(0.042<0.05)$ indicated that the capital structure has a negative effect on profitability.

These results were conformable with research shepherded with Meithasari (2017), which showed that capital structure has a negative effect on profitability. It can be clarified from the data's value on the sample of manufacturing companies in 2016-2018 in this study. For example, the Siantar Top Tbk (STTP) company in 2016 had a DER value of 0.99 with a ROA value of 0.074 . In 2017, the company's DER value decreased to 0.69 , where the decrease in DER value was followed by an increase in the ROA value, namely to 0.092. Something similar happened in 2018, where the DER value decreased again to 0.59 and was followed by an increase in the ROA value to 0.097 .

From this explanation, it can be concluded that a decrease in the DER value will increase the ROA value. It means that the use of less and less debt will increase the company's profit because there are fewer obligations to be paid by the company so that the company's income does not decrease much to bear the firm's liability. Thus, it can be determined that the capital structure represented by the debt to equity ratio (DER) has a negative effect on profitability.

\section{The Effect of Firm Size on Corporate Value}

The company size variable is 2.497 , with a significance of 0.014 based on regression analysis results. It shows that corporate value in the Indonesian Stock Exchange manufacturing sector for 2016-2018 is positively affected by the firm size. 
This study is in tune with Istamarwati \& Suseno (2017) research, which declare that company size has a positive effect on firm value. It can be explained from the data on the sample of manufacturing companies in 2016-2018 in this study. For example, Semen Indonesia Tbk (SMGR), in 2016, had a SIZE value of 31.42 with a PBV value of 1.78. In 2017 the company's SIZE value increased to 31.52, followed by an increased PBV value to 1.95. A similar thing also happened in 2018, where the SIZE value increased again to 31.57 and was followed by a larger PBV value, namely to 2.08 .

Thus, in this study, the greater the company's size, the greater the firm value, where large companies will be considered better and have more promising prospects to increase investor confidence and increase company value. Therefore, these results indicate that firm size has a significant positive effect on firm value.

\section{The Effect of Capital Structure on Corporate Value}

Based on the regression analysis results, the capital structure variable had a t-value of -0.472 with a significance level of 0.638 . A significance value bigger than $0.05(0.638>0.05)$ indicated that the capital structure does not affect the value of manufacturing sector companies listed on the Indonesia Stock Exchange.

This study contradicted Ardiansyah (2019), which revealed that capital structure has a negative effect on firm value. However, these results were fitted with Rusdaniah (2019), which showed that capital structure does not affect firm value. This result can be explained from the data's value on manufacturing companies' sample in 2016-2018 in this study. The company data in this study shows that of the 30 companies observed for three periods, only seven companies or $23 \%$ showed a negative influence consistently for three periods, or it can be said that a decrease in DER value will increase the PBV value and the addition of DER value always decreases PBV value. While the rest, 23 companies or $77 \%$, did not show any consistent negative effect for three periods, or it can be said that the change in DER value did not affect the increase or decrease in the value of firm value. For example, the Ateliers Mecaniques D Indonesia Tbk (AMIN) Company in 2016 had a DER value of 0.56 with a PBV value of 2.32. In 2017, the company's DER value increased to 0.67, where the increase in DER value was followed by an increase in the PBV value, namely to 2.85. In 2018 the DER value, which again increased to 0.98 , was not followed by an increase in the PBV value. In 2018 the PBV value decreased to 2.54 .

From this description, it can be concluded that the increase in DER value in 2017 also increased the value of firm value, but in 2018 the increase in DER value decreased the value of the firm's firm value. Thus it can be concluded that the capital structure represented by the debt to equity ratio (DER) does not affect firm value.

\section{The Effect of Profitability on Corporate Value}

The profitability variable was $6,518 \mathrm{t}$-value, with a significance of 0,000 , based on the results of regression analyses. Significant less than $0.05(0.000<0.05)$ indicates positive impact on the value of manufacturing firms.

This study was consistent with Ardiansyah (2019) research, which stated that profitability had a positive effect on corporate value. This result can be explained from the data's value on manufacturing companies' sample in 2016-2018 in this study. For example, the Gudang Garam Tbk (GGRM) Company, in 2016, the company had a ROA value of 0.106 with a PBV value of 3.11. In 2017, the ROA value of Gudang Garam Tbk (GGRM) Company increased to 0.116, which was followed by an increase in PBV value to 3.82. In contrast to 2017, in 2018, the Gudang Garam Tbk (GGRM) company experienced a decrease in ROA value, namely to 0.112 . This decrease in ROA value was followed by a decrease in PBV value, namely to 3.57.

Based on this description, it can be determined that an increase will follow an increase in the ROA value in the PBV value. In the chorus, a decrease in the ROA value will also decrease the PBV value. In other words, the profitability represented by ROA has a positive effect on firm value (PBV). 


\section{The Influence of Firm Size on Corporate Value with Profitability as an Mediating Variable}

Based on the path analysis, the SIZE beta value against PBV on Standardized Coefficients was 0.210, and the beta ROA value against PBV on Standardized Coefficients was 0.562. At the same time, the SIZE beta value against ROA on Standardized Coefficients showed the number 0.255. To see whether profitability could mediated firm size on firm value, direct and indirect effects were calculated.

Based on the calculation results, the indirect influence between SIZE and PBV was obtained, which was 0.353. At the same time, the value of the direct influence between SIZE on PBV was 0.210. The value of the indirect effect was bigger than the direct effect or $0.353>0.210$. This result depicted that there was an indirect effect on SIZE on PBV through ROA.

This research was in line with Rusdaniah (2019), which states that profitability can mediate company size's effect on firm value. The results in this research indicate that the bigger a company is showing that the company can manage its business well, so that the opportunity to get a profit is higher, where higher profits will increase firm value. In other words, profitability can become an intervening variable in firm size's effect on firm value. Thus the sixth hypothesis is accepted.

\section{The Effect of Capital Structure on Corporate Value with Profitability as an Mediating Variable}

Based on the path analysis, the DER beta value against PBV on Standardized Coefficients showed a number of -0.039 , and the beta ROA value against PBV on Standardized Coefficients was 0.562 . In contrast, the DER beta value against ROA on Standardized Coefficients showed the number -0.209 . Where to see whether profitability could intervene the capital structure on corporate value, direct and indirect effects were calculated.

Based on the calculation results, it was found that the indirect effect between capital structure (DER) on firm value (PBV) was -0.156. Meanwhile, the direct effect value between DER and PBV was 0.039 . Based on the calculation, the indirect effect's value was smaller than the direct effect or -0.156 $<-0.039$. This result indicated that there was no indirect effect on DER on PBV through ROA. In other words, it can be said that the increase in profit caused by a reduction in debt does not affect the investor's view of the corporate's value.

This research contradicted research conducted by Rusdaniah (2019), which stated that profitability could intervene with the capital structure on firm value. However, this study was consistent with Ardiansyah (2019), who stated that profitability could not mediate capital structure on corporate value. To sum up, profitability cannot intervene with the effect of capital structure on corporate value.

Based on the F-test, the calculated F-value of 5,479 is 0.006 for model 1. A value of less than 0.05 showed that the model could predict the profitability of the corporate sizes and capital structure. In model 2, the F test value was several 21,887 with a statistical level of 0.000 . This result showed that the model could predict the effect of size, profitability, and capital structure on corporate value.

\section{CONCLUSION}

Size has a positive effect on profitability and corporate value. In contrast, capital structure has a negative effect on profitability. Meanwhile, the capital structure does not affect firm value. Profitability positively affects firm value, while profitability can be an intervening variable in firm size's effect on corporate value. Profitability cannot be an intervening variable in the effect of the company's capital structure on firm value.

For further researchers, it is expected to develop research by adding other factors that can affect firm value. Besides, it is hoped that the next researcher will increase the number of samples and the observation period.

\section{REFERENCES}

Anisa, H. (2019). Pengaruh Struktur Modal, Ukuran Perusahaan dan Keputusan Investasi terhadap

JMER, 2020, 01(2), 67-76 
Nilai Perusahaan dengan Profitabilitas sebagai Variabel Intervening (Studi Kasus Perusahaan Manufaktur yang Terdaftar di Daftar Efek Syariah Periode 2015-2018). IAIN SALATIGA.

Ardiana, E., \& Chabachib, M. (2015). Analisis Pengaruh Struktur Modal, Ukuran Perusahaan dan Likuiditas terhadap Nilai Perusahaan dengan Profitabilitas sebagai Variabel Intervening (Studi pada Perusahaan Consumer Goods yang Terdaftar di BEI pada Tahun 2012-2016). Diponegoro Journal of Management, 7(2), 1-14.

Ardiansyah, A. (2019). Analisis Pengaruh Struktur Modal dan Ukuran Perusahaan terhadap Nilai Perusahaan dengan Profitabilitas sebagai Variabel Intervening (Studi Kasus pada Perusahaan yang Terdaftar di Indeks Saham Syariah Indonesia (ISSI)). IAIN SALATIGA.

Astriana, G., Nurcholisah, K., \& Nurhayati, N. (2019). Pengaruh Struktur Modal dan Ukuran Perusahaan terhadap Nilai Perusahaan (Studi Empiris pada Perusahaan Sektor Aneka Industri yang Terdaftar di Bursa Efek Indonesia Periode Tahun 2015-2016).

Astuti, W. N. (2018). Pengaruh Struktur Modal, Profitabilitas dan Ukuran Perusahaan Terhadap Nilai Perusahaan (Studi Empiris Perusahaan Manufaktur yang Terdaftar di Bursa Efek Indonesia Tahun 2013-2016). Universitas Muhammadiyah Surakarta.

Brigham, E. F., \& Houston, J. F. (2016). Fundamentals of Financial Management (Ninth). Boston: Cengage Learning.

Darya, I. G. P., \& Putu, G. (2019). Akuntansi Manajemen. Ponorogo: Uwais Inspirasi Indonesia.

Dewi, A. S. M., \& Wirajaya, A. (2013). Pengaruh Struktur Modal, Profitabilitas dan Ukuran Perusahaan pada Nilai Perusahaan. E-Jurnal Akuntansi, 4(2), 358-372.

Dewi, D. A. I. Y. M., \& Sudiartha, G. M. (2017). Pengaruh Profitabilitas, Ukuran Perusahaan, dan Pertumbuhan Aset terhadap Struktur Modal dan Nilai Perusahaan. E-Jurnal Manajemen Universitas Udayana, 6(4), 2222-2252.

Dwiastuti, D. S., \& Dillak, V. J. (2019). Pengaruh Ukuran Perusahaan, Kebijakan Hutang, dan Profitabilitas terhadap Nilai Perusahaan. Jurnal ASET (Akuntansi Riset), 11(1), 137-146.

Gitman, L. J., \& Zutter, C. D. (2015). Principle of Managerial Finance (Fourteenth). United States of America: Pearson Education Limited.

Hasanah, A., \& Enggariyanto, D. (2018). Analisis Faktor-faktor yang Mempengaruhi Return On Asset pada Perusahaan Manufaktur yang Terdaftar di Bursa Efek Indonesia. Journal of Applied Managerial Accounting, 2(1), 15-25.

Hermuningsih, S. (2012). Pengaruh Profitabilitas, Size terhadap Nilai Perusahaan dengan Struktur Modal sebagai Variabel Intervening. Jurnal Siasat Bisnis, 16(2), 232-242.

Husnan, S. (2000). Manajemen Keuangan Teori dan Penerapan (Keputusan Jangka Panjang). Yogyakarta: BPFE.

Hutabarat, W. D., Sedana, P., \& Bagus, I. (2017). Pengaruh Ukuran Perusahaan, Suku Bunga dan Struktur Modal terhadap Profitabilitas. E-Jurnal Manajemen Universitas Udayana, 6(12), 69136931.

Indriyani, E. (2017). Pengaruh Ukuran Perusahaan dan Profitabilitas terhadap Nilai Perusahaan. Akuntabilitas: Jurnal Ilmu Akuntansi, 10(2), 333-348.

Istamarwati, Y., \& Suseno, D. (2017). Pengaruh Ukuran Perusahaan dan Debt to Equity Ratio terhadap Nilai Perusahaan dengan Profitabilitas sebagai Variabel Intervening. Jurnal Manajemen Sumber Daya Manusia, 11(1), 148-162.

Mardiyati, U., Abrar, M., \& Ahmad, G. N. (2015). Pengaruh Keputusan Investasi, Keputusan Pendanaan, Ukuran Perusahaan dan Profitabilitas terhadap Nilai Perusahaan pada Sektor Manufaktur Barang Konsumsi yang Terdaftar di Bursa Efek Indonesia Periode 2010-2013. JRMSI-Jurnal Riset Manajemen Sains Indonesia, 6(1), 417-439.

Margaretha, F., \& Ramadhan, A. R. (2010). Faktor-faktor yang Mempengaruhi Struktur Modal pada Industri Manufaktur di Bursa Efek Indonesia. Jurnal Bisnis Dan Akuntansi, 12(2), 119-130.

Meithasari, R. (2017). Analisis Faktor-faktor yang Mempengaruhi Profitabilitas. Universitas Negeri Yogyakarta.

Narita, R. M. (2012). Analisis Kebijakan Hutang. Accounting Analysis Journal2, 1(2), 1-6.

Pratiwi, L. (2018). Pengaruh Kebijakan Utang dan Kebijakan Dividen terhadap Nilai Perusahaan dengan Profitabilitas sebagai Variabel Intervening. Universitas Kristen Maranatha.

Rahayu, M., \& Sari, B. (2018). Faktor-faktor yang Mempengaruhi Nilai Perusahaan. IKRA-ITH

JMER, 2020, 01(2), 67-76 
HUMANIORA: Jurnal Sosial Dan Humaniora, 2(1), 69-76.

Riduwan, E. A. K., \& Kuncoro, A. (2012). Cara Menggunakan dan Memaknai Path Analysis (Analisis Jalur). Bandung: Alfabeta.

Rusdaniah, D. R. (2019). Analisis Pengaruh Struktur Modal, Likuiditas dan Ukuran Perusahaan terhadap Nilai Perusahaan dengan Profitabilitas sebagai Variabel Mediasi. Universitas Negeri Yogyakarta.

Sukmayanti, N. W. P., \& Triaryati, N. (2019). Pengaruh Struktur Modal, Likuiditas dan Ukuran Perusahaan terhadap Profitabilitas pada Perusahaan Property dan Real Estate. E-Jurnal Manajemen2, 8(1), 172-202.

Umar, H. (2005). Metode Riset Bisnis (1 st ed.). Jakarta: Gramedia Pustaka Utama.

Widyantari, N. L. P., \& Yadnya, I. P. (2017). Pengaruh Struktur Modal, Profitabilitas dan Ukuran Perusahaan terhadap Nilai Perusahaan pada Perusahaan Food and Baverage. E-Jurnal Manajemen Universitas Udayana, 6(12), 6383-6409.

Wikardi, L., \& Wiyani, N. (2017). Pengaruh Debt To Equity Ratio, Firm Size, Inventory Turnover, Assets Turnover dan Pertumbuhan Penjualan terhadap Profitabilitas (Studi Kasus pada Industri Makanan dan Minuman yang Terdaftar di BEI Periode 2011-2015). Jurnal Online Insan Akuntan, 2(1), 234099. 